\title{
Intracavernous administration of adipose stem cells: a new technique of treating erectile dysfunction in diabetic patient, preliminary report of 6 cases
}

\begin{abstract}
Objectives: After revolutionized treatment of erectile dysfunction (ED) with phosphodiesterase-5 inhibitors (PDE5) inhibitors, approximately $30 \%$ of patients are non-responsive. An important cause of this is vascular and smooth muscle dysfunction, as well as nerve atrophy. Stem cells are characterized by anti-inflammatory activities, as well as possibility of differentiating into tissue relevant to the penile architecture, and stimulation of angiogenesis. We report the effects of intracavernosal application of adipose derived stem cells (ASC) on diabetic erectile dysfunction.
\end{abstract}

Materials and methods: Six type 2 diabetics who had failed to achieve an erection for at least 6 months despite medications, and who are currently awaiting penile prostheses, participated in this study. All laboratory results were normal, except for erectile dysfunction and diabetes mellitus. A total of $1.5 \times 107$ adipose stem cells was infused into the corpus cavernosum. No immunosuppressive measures were taken in any of the patients. International index of erectile function-5, Encounter Profile Question 3 (SEP3), erection diary, blood glucose diary, and medication dosage were followed for 6 months.

Results: The mean age was 63.7years (range, 55-81years). Morning erections were recovered in 4 participants within 2 months, and for all except 1 by the 95 days, and maintained for more than 4months. Rigidity increased as the result of stem cell therapy alone, but was insufficient for penetration. With the addition of PDE5 inhibitor before coitus, 3 achieved penetration and experienced orgasm, and maintained for more than 6months. All but 1 reported increased desire. During follow-up, 1 returned for prosthesis, 1 returned to a nonerectile condition at 7 months, and 4 maintained erection sufficient for coitus with medication until the $9^{\text {th }}$ month. Blood glucose levels decreased by 2 weeks, and medication dosages were reduced in all. Glycosylated hemoglobin levels improved after treatment.

Conclusion: Human adipose stem cell therapy has positive effects on erectile dysfunction in diabetes mellitus patients. Stem cells mediate mechanism may contribute to these positive effects

Keywords: stem cell treatment, erectly dysfunction, pde5 inhibitors, diabetes, adipose stem cell therapy, regenerative medicine
Volume 2 Issue I - 2015

Garber MG, Carlos ND

Department regenerative medicine, Clinica Medica Quirurgica Quantum, Spain

Correspondence: Garber Miguel Guillermo, Department regenerative medicine, Clinica Medica Quirurgica Quantum, Clara del Rey 3I-33, Madrid, 28002, Spain, Tel 628766753, Email mggarber@gmail.com

Received: June 18, 2014 | Published: March 02, 2015
Abbreviations: NO, nitric oxide; NANC, non adrenergic non cholinergic; ED, erectile dysfunction; PDEIs, phosphodiesterase-5 inhibitors; ASC, adipose stem cells; IIEF, international index of erectile function; SC, stem cells; MSC, mesenchymal stem cells; T2D, type 2 diabetes; IRS 1, insulin receptor substrate 1

\section{Introduction}

The hemodynamic phenomena of erection are regulated by penile smooth muscle tone (arterial and trabecular). This response requires a coordinated process, increases in arterial inflow, originates from the pudenda arteries, relaxation of the corporal smooth muscle, and inhibition of venous outflow. ${ }^{1,2}$ Key to this response is production of nitric oxide (NO) from endothelial cells and non adrenergic non cholinergic (NANC) postganglionic parasympathetic neurons, as well as responsiveness to this. ${ }^{3}$ The current treatments for erectile dysfunction(ED) include psychotherapy, oral or injected medication, and penile prosthesis. Oral treatment with phosphodiesterase-5 inhibitors (PDE5Is) as a first-line monotherapy, ${ }^{4}$ but, a significant proportion of patients with complex $\mathrm{ED}^{5}$ are non-responsive (approximately $30 \%$ of patients). ${ }^{6}$ An important cause of this is vascular and smooth muscle dysfunction, ${ }^{7}$ as well as nerve atrophy.

In diabetes, the activities of vasoconstrictors such as Angiotensin II, endothelin-,${ }^{8}$ and vascular endothelial growth factor are increased. ${ }^{7}$ The chronic complications of diabetes mellitus affect multiple organs and cause microvascular and macro vascular complications, in addition to nonvascular complications. Erectile dysfunction is the second most-common symptom of diabetes mellitus, ${ }^{9}$ and affects $32 \%$ of men with type 1 diabetes and $46 \%$ of men with type 2 diabetes. Erectile dysfunction is caused by the impaired relaxation of corporal smooth muscle cells. ${ }^{10}$ This condition is thought to be induced by a combination of disorders in the central or peripheral nervous system, hormone production, vascular integrity, or endothelial smooth muscle, as well as psychological and other factors. ${ }^{11,12}$ Stem cells hold great promise for regeneration because of their ability to self- 
renewal, potentiality for differentiation, and homing or migration, depending on the stimuli received. Some types of adult stem cells, which exist within matured organs, are now clinically available, and their therapeutic effects have been firmly established. Adult stem cells may prove invaluable in the development of new therapeutic applications for a variety of incurable or difficult-to-cure diseases. ${ }^{13-18}$ The adipose-tissue-derived stem cells (ASC) are similar to bone marrow stem cell in the ability to differentiate, provide therapeutic benefit, and the easy and safety of cell harvest. Adipose tissue is a potential source of stem cells for treatment of erectile dysfunction, which highlights the possibility of an effective clinical therapy. ${ }^{19-21}$ Stem cells are characterized by multipotent differentiation, and stimulation of angiogenesis/regeneration. We report the effects of intracavernosal application of adipose stem cells (ASC) on diabetic erectile dysfunction patients.

\section{Materials and methods}

\section{Characteristics of participants}

Six diabetics type 2 patients who had failed to achieve an erection for at least 6 months despite medications, (oral phosphodiesterase 5 inhibitor, (PDE5 inhibitor), or prostaglandin E1, (PGE1) injection), for a mean of 63.7years (range, 55-81years), and who are currently awaiting penile prostheses, participated in this study. This study, which confirms the ethical guidelines of the 1975 Helsinki Declaration, was conducted as a master protocol study and all participants were informed of the materials (stem cells) and the nature of treatments to be used; additionally, written informed consent was obtained from all of the subjects. International index of erectile function-5 and sexual encounter profile questionnaires, and standard erectile dysfunction evaluations, including medical history, thorough physical examination, testosterone and prolactin levels, and penile duplex Doppler ultrasonography were performed for all patients.

Among many candidates, only those individuals with a body mass index between 19 and 23 were included in this study. To exclude patients that might have diseases, other than diabetes mellitus and erectile dysfunction, all participants were subjected to ancillary tests, including blood and serologic studies (CBC, serologic series 12 including lipids, tumor markers $<$ AFP, CEA, CA19-9, PSA $>$, VDRL, AIDS, hepatitis Ag/Ab, H. pylori, electrolytes, C-reactive protein, ASO titer, ESR, RA factor) tests, urine studies (urine analysis, microscopic examination), imaging studies (ultrasound examinations for thyroid, heart, liver, kidney, and prostate; and computed tomography scans for brain, chest, and abdomen), electrocardiogram, and funduscopy. All participants had only diabetes mellitus and erectile dysfunction but were within normal range for testosterone and prolactin (testosterone levels were examined every visit during follow-up). Anybody with an abnormal finding on these ancillary studies was excluded from this study. No immunosuppressive measures were applied. International index of erectile function- 5 and blood glucose were monitored for 6 to 12 months. The patients' hormonal levels were checked every visit.

\section{Characteristics of adipose stem cells}

Human adipose tissues were obtained by simple liposuction from the abdominal subcutaneous fats with an informed consent. Subcutaneous adipose tissues were digested with collagenase I (1mg/ $\mathrm{mL}$ ) for the enzymatic digestion of adipose tissue with collagenase type IA and the isolation of the SVF via centrifugation. Plating of the SVF results in eventual selection and expansion of the Adult Stem Cells (ASCs) population. They yield reached around $1 \times 10^{6}$ ASCs per gram adipose tissue, and CD29, CD34, CD44, CD45 and CD105 were detected by flow cytometry. The detection rates of CD29, CD44, CD105, CD34 and CD45 were $98.89 \%, 93.73 \%, 86.99 \%, 0.19 \%$ and $0.16 \%$. The $1.8 \times 10^{7}$. The stem cells were infused into the both corpus cavernosum of each patient. The penile root was clamped with a band before injection and released 30minutes after the adipose stem cells were injected to prolong the transplanted cell residence time, and increase the graft.

\section{Follow-up}

All participants submitted an international index of erectile function questionnaire (Table 1) at every visit, before a followup interview. The international index of erectile function (IIEF) questionary addresses the relevant domains of male sexual function (that is, erectile function, orgasmic function, sexual desire, intercourse satisfaction, and overall satisfaction), is psychometrically and has been linguistically validated in 10 languages. The IIEF demonstrates the sensitivity and specificity for detecting treatment-related changes in patients with erectile dysfunction. Dosages of a hypoglycemic agent or insulin declined during periods in which the blood glucose level dropped below $5.55 \mathrm{mmol} / \mathrm{L}(100 \mathrm{mg} / \mathrm{mL})$. All patients were instructed to use the PDE5 inhibitor when they wished to engage in sexual intercourse after the stem cell therapy. All patients monitored their fasting blood sugar at home every day, and monthly at the hospital, and their glycosylated hemoglobin levels also were checked monthly at the hospital. Participants were encouraged to reduce their medication dosage when the fasting blood sugar fell below $5.55 \mathrm{mmol} / \mathrm{L}(100 \mathrm{mg} / \mathrm{mL})$ to prevent hypoglycemia. For each patient, an erection diary, blood glucose diary, and medication dosage were recorded daily, and the patients were followed for 12 months.

Table I The IIEF-5 Questionnaire (SHIM)

\begin{tabular}{|c|c|c|c|c|c|c|}
\hline & Over the past 6 months & & & & & \\
\hline \multirow{2}{*}{ I } & \multirow{2}{*}{$\begin{array}{l}\text { How do you rate your confidence that you could get and } \\
\text { keep an erection }\end{array}$} & Very low & Low & Moderate & High & Very high \\
\hline & & I & 2 & 3 & 4 & 5 \\
\hline \multirow{2}{*}{2} & \multirow{2}{*}{$\begin{array}{l}\text { When you had erections with sexual stimulation, how } \\
\text { often were your erections hard enough for penetration? }\end{array}$} & $\begin{array}{l}\text { Almost } \\
\text { never or } \\
\text { never }\end{array}$ & A few times & Sometimes & Most times & $\begin{array}{l}\text { Almost } \\
\text { always or } \\
\text { always }\end{array}$ \\
\hline & & I & $\begin{array}{l}\text { (Much less than } \\
\text { half the time) } \\
2\end{array}$ & $\begin{array}{l}\text { About half } \\
\text { the time } \\
3\end{array}$ & $\begin{array}{l}\text { Much more than } \\
\text { half the time } \\
4\end{array}$ & 5 \\
\hline
\end{tabular}


Table Continued....

\begin{tabular}{|c|c|c|c|c|c|c|}
\hline & Over the past 6 months & & & & & \\
\hline 3 & $\begin{array}{l}\text { During sexual intercourse, how often were you able to } \\
\text { maintain your erection after you had penetrated your } \\
\text { partner? }\end{array}$ & $\begin{array}{l}\text { Almost } \\
\text { never or } \\
\text { never } \\
\text { I }\end{array}$ & $\begin{array}{l}\text { A few times } \\
\text { (Much less than } \\
\text { half the time) } \\
2\end{array}$ & $\begin{array}{l}\text { Sometimes } \\
\text { (About half } \\
\text { the time) } \\
3\end{array}$ & $\begin{array}{l}\text { Most times } \\
\text { (Much more than } \\
\text { half the time) } \\
4\end{array}$ & $\begin{array}{l}\text { Almost } \\
\text { always or } \\
\text { always }\end{array}$ \\
\hline 4 & $\begin{array}{l}\text { During sexual intercourse, how difficult was it to maintain } \\
\text { your erection to completion of intercourse? }\end{array}$ & $\begin{array}{l}\text { Extremely } \\
\text { difficult } \\
\text { I }\end{array}$ & Very difficult & Difficult & Slightly difficult & $\begin{array}{l}\text { Not difficult } \\
5\end{array}$ \\
\hline 5 & $\begin{array}{l}\text { When you attempted sexual intercourse, how often was it } \\
\text { satisfactory for you? }\end{array}$ & $\begin{array}{l}\text { Almost } \\
\text { never or } \\
\text { never }\end{array}$ & $\begin{array}{l}\text { A few times } \\
\text { (Much less than } \\
\text { half the time) } \\
2\end{array}$ & $\begin{array}{l}\text { Sometimes } \\
\text { (About half } \\
\text { the time) } \\
3\end{array}$ & $\begin{array}{l}\text { Most times } \\
\text { (Much more than } \\
\text { half the time) } \\
4\end{array}$ & $\begin{array}{l}\text { Almost } \\
\text { always or } \\
\text { always }\end{array}$ \\
\hline
\end{tabular}

Please encircle the response that best describes you for the following five questions.

Total Score:

I-7: Severe ED; 8-I I: Moderate ED; I2- I6: Mild-moderate ED; I7-2I: Mild ED; 22-25: No ED

\section{Results}

The 6 participants ages ranged from 59.4years (range, 55-72years). Penile duplex Doppler ultrasonography was conducted for all 6 participants before stem cell therapy, and these records demonstrated that all had reduced peak systolic velocities in both cavernosal arteries-less than $22 \mathrm{~cm} / \mathrm{sec}$. All participants exhibited some inconsistent changes in testosterone levels on their follow-ups, but these variations were within normal limits. Additionally, some changes in international index of erectile function- 5 scores were noted. Among the 6 experimental participants who, before treatment, had no erections in the morning or during sexual activity, 4 experienced morning erections by 1 month after treatment, and the second month all but 1 regained morning erections (question 1); this was maintained for 12 months. Six of the experimental participants experienced increases in penile hardness with time from stem cell therapy only; however, the degree of increased hardness was still insufficient for effective penetration in one patient. With the addition of a PDE5 inhibitor (sildenafil citrate $100 \mathrm{mg}$ ), 5 could achieve penetration, maintenance, and orgasm, and retained that ability (questions 3 and 4) at the sixth month after treatment. At 12 months' follow-up, case 2 reported not being able to maintain penetration, even when using the PDE5 inhibitor. All expressed desire before and after cell therapy, and all but 1 participant reported an increased desire in both frequency and intensity after stem cell treatment. Hormonal levels exhibited individual and intrapersonal variations at each test, but again, all remained within normal range. During 12 months follow-up, 1 participant turned for prosthesis, 1 could achieve only poor erections at 10 months, and 4 patients maintained erection sufficient for coitus with the help of medication. Three of the patients who could achieve penetration and maintenance also experienced orgasm. With regard to the effects of stem cells on erectile dysfunction, (4/6) of the subjects agreed that stem cell therapy applied alone had some effect on erectile dysfunction, although this effect was insufficient (question 13), and 5 $(5 / 6)$ of the subjects regarded stem cell therapy as effective for erectile dysfunction when combined with a PDE 5 inhibitor.
Subjects blood glucose levels began to drop from 2 weeks after treatment, and 5 of 6 evidenced some reduction in fasting blood sugar by 3 month. The insulin dosage had to be dropped at 1 month in 2 cases owing to lower fasting blood sugar (lower than $5.55 \mathrm{mmol} / \mathrm{L}(100 \mathrm{mg} /$ $\mathrm{mL}$ ); and at 4 months, a hypoglycemic agent had to be reduced to maintain blood glucose levels at above $5.5 \mathrm{mmol} / \mathrm{L}(100 \mathrm{mg} / \mathrm{mL})$. The most elderly of the subjects (No. 6) evidenced no changes in blood glucose levels after stem cell therapy. Glycosylatedhemoglobin's improved beginning in the third month after treatment in all patients. The lowered blood glucose levels in each patient. There were no adverse effects after stem cell therapy, even without immune suppression. Overall, only 1 patient reported confidence in the effects of stem cell therapy on erectile dysfunction without a PDE5 inhibitor.

\section{Discussion}

Stem Cells (SC) therapy for chronic disease has been investigated in several preclinical studies and clinical trials, Adipose Stem Cell (ASC) is the most commonly employed SC, likely due to its ease of isolation from an abundant tissue source. The rationale for adipose derivates stem cell therapy of patients with erectile dysfunction is strong set that:

i. The penile vasculature is the most endothelial-rich anatomical region of the body, thus even a small amount of therapeutic cells are likely to be incorporated

ii. Blood flow in the flaccid penis is slower compared to systemic circulation, thus allowing for superior retention

iii. Ease of injection given its external location.

From an ethical perspective, the procedure of penile prosthesis implantation requires destruction of the cavernous, thus making it irreversible. The reduction in fasting blood glucose can be explained investigative trials show (Mesenchymal Stem cells (MSC) infusion ameliorated hyperglycemia in rats with type 2 diabetes (T2D). Infusion of MSCs during the early phase promoted $\beta$-cell function, 
also ameliorated insulin resistance, whereas infusion in the late phase merely ameliorated insulin resistance. Infusion of MSCs resulted in an increase of GLUT4 expression and an elevation of phosphorylated insulin receptor substrate 1 (IRS-1) and Akt (protein kinase B) in insulin target tissues. These data indicate that multiple roles and mechanisms are involved in the efficacy of MSCs in ameliorating hyperglycemia in T2D. ${ }^{22}$

\section{Conclusion}

Even though in the study we performed, the sample is rather small; we can infer that the use of Adipose derived stem cell therapy has positive effects on erectile dysfunction in diabetes mellitus patients. Taking into consideration this type of population, bombarded all day with "magic potions" as well as they reticence regarding surgical option, the practicability of the injection procedure, the fact that no adverse effects were observed, and the simplicity of the procedure, supports expanded clinical trials using this kind of intervention may be added to the already vast armamentarium in the treatment of ED. Maybe using this therapy prophylactically, implementing early in the treatment of patient with DM, before the onset of ED symptoms, may prevent or delay the early onset of the one most distressing side effect of this debilitating disease that, Diabetes Mellitus truly is, the feasibility of the injection procedure, the fact that no adverse effects were noted, and the ease of the procedure, supports expanded clinical trials using this intervention will be needed.

\section{Acknowledgements}

None.

\section{Conflict of interest}

The author declares no conflict of interest.

\section{References}

1. Andersson KE, Wagner G. Physiology of penile erection. Physiol Rev. 1995;75(1):191-236

2. Fournier GR, Juenemann KP, Lue TF, et al. Mechanisms of venous occlusion during canine penile erection: an anatomic demonstration. $J$ Urol. 1987;137(1):163-167.

3. Toda N, Ayajiki K, Okamura T. Nitric oxide and penile erectile function. Pharmacol Ther. 2005;106(2):233-266.

4. Ravipati G, McClung JA, Aronow WS, et al. Type 5 phosphodiesterase inhibitors in the treatment of erectile dysfunction and cardiovascular disease. Cardiol Rev. 2007;15(2):76-86.

5. Lue T, Broderick G. Evaluation and nonsurgical management of erectile dysfunction and premature ejaculation. In: Walsh PC, et al. editors. Campbell's Urology. 9th ed. USA: WB Saunders; 2006. p. 750-877.

6. Vickers MA, Wright EA. Erectile dysfunction in the patient with diabetes mellitus. Am J Manag Care. 2004;10(1 Suppl):S3-S11.
7. Jansson PA. ndothelial dysfunction in insulin resistance and type 2 diabetes. J Intern Med. 2007;262(2):173-183.

8. Tousoulis D, Tsarpalis K, Cokkinos D, et al. Effects of insulin resistance on endothelial function: possible mechanisms and clinical implications. Diabetes Obes Metab. 2008;10(10):834-842.

9. Goldstraw MA, Kirby MG, Bhardwa J, et al. Diabetes and the urologist: a growing problem. BJU Int. 2007;99(3):513-517.

10. Saenz de Tejada I, Goldstein I, Azadzoi K, et al. Impaired neurogenic and endothelium-mediated relaxation of penile smooth muscle from diabetic men with impotence. N Engl J Med. 1989;320(16):1025-1030.

11. Dunsmuir WP, Holmes SA. The aetiology and management of erectile, ejaculatory and fertility problems in men with diabetes mellitus. Diabet Med. 1996;13(8):700-708.

12. Wierman ME, Cassel CK. Erectile dysfunction: a multifaceted disorder Hosp Pract. 1998;(1995) 33(10):65-74.

13. Bengel FM, Schachinger V, Dimmeler S. Cell-based therapies and imaging in cardiology. Eur J Nucl Med Mol Imaging. 2005;32(Suppl 2):S404-S416.

14. Escolar ML, Poe MD, Provenzale JM, et al. Transplantation of umbilical-cord blood in babies with infantile Krabbe's disease. $N$ Engl J Med. 2005;352(20):2069-2081.

15. Reffelmann T, Koenemann S, Kloner RA. Promise of blood-and bone marrow-derived stem cell transplantation for functional cardiac repair:putting it in perspective with existing therapy. $\mathrm{J} \mathrm{Am} \mathrm{Coll} \mathrm{Cardiol.}$ 2009;53(4):305-308.

16. Yoshimura K, Sato K, Aoi N, et al. Cell-assisted lipotransfer for facial lipoatrophy: efficacy of clinical use of adipose derived stem cells. Dermatol Surg. 2008;34(9):1178-1185.

17. Yu G, Borlongan CV, Stahl CE, et al. Systemic delivery of umbilical cord blood cells for stroke therapy: a review. Restor Neurol Neurosci. 2009;27(1):41-54.

18. Lin CS, Xin ZC, Deng CH, et al. Recent advances in andrology-related stem cell research. Asian J Androl. 2008;10(2):171-175.

19. Song YS, Lee HJ, Park IH, et al. Human neural crest stem cells transplanted in rat penile corpus cavernosum to repair erectile dysfunction. BJU Int. 2008;102(2):220-224.

20. Song YS, Ku JH, Song ES, et al. Magnetic resonance evaluation of human mesenchymal stem cells in corpus cavernosa of rats and rabbits. Asian J Androl. 2007;9(3):361-367.

21. Nolazco G, Kovanecz I, Vernet D, et al. Effect of muscle-derived stem cells on the restoration of corpora cavernosa smooth muscle and erectile function in the aged rat. BJU Int. 2008;101(9):1156-1164.

22. Si Y, Zhao Y, Hao H, et al. Infusion of Mesenchymal Stem Cells Ameliorates Hyperglycemia in Type 2 Diabetic Rats: Identification of a Novel Role in Improving Insulin Sensitivity. Diabetes. 2012;61(6):16161625 . 